\title{
Pengembangan Kompetensi Spiritual Supervisor dalam Layanan Konseling
}

\author{
Diana Dewi Wahyuningsih \\ Universitas Tunas Pembangunan Surakarta
}

dianadewi_81@yahoo.com

\begin{abstract}
Abstrak
Kompetensi terbaru yang ditetapkan untuk menangani isuisu spiritual dan keagamaan dalam konseling (Association of Spiritual, Ethical, and Religious Values in Counseling, 2009) di dalamnya memberikan pedoman pada konselor untuk menerapkan praktek konseling berdasarkan petunjuk yang ditentukan. Kompetensi spiritual ini melengkapi kode etik yang ditetapkan oleh The American Counseling Association (2014) untuk memberi dukungan dalam meningkatkan kepekaan lintas budaya dan keahlian dalam konseling. Alat pengawasan yang mendukung pengembangan etis dan spiritual konselor dalam pelatihan konseling, telah dijelaskan dan diidentifikasi.
\end{abstract}

Kata kunci: spiritual, kompetensi, supervisi.

\begin{abstract}
The latest competencies set out to deal with spiritual and religious issues in counseling provide guidance to counselors to implement counseling practices based on specified guidance. This spiritual competence complements the code of ethics set by The American Counseling Association (2014) to provide support in enhancing cross-cultural sensitivity and counseling expertise. Supervisory tools that support the ethical and spiritual development of counselors in counseling training have been described and identified. Keywords: spiritual, competence, supervision.
\end{abstract}




\section{Diana Dewi Wahyuningsih}

\section{A. Latar Belakang}

Beberapa pelatihan baru telah dirancang untuk mengeksplorasi masalah - masalah spiritual yang terjadi dalam konseling. Topik - topik seperti pemahaman spiritual, penilaian kebutuhan spiritual klien, dan mengidentifikasi masalah spiritual dalam konseling didiskusikan didalam kerangka multicultural (Fukuyama \& Sevig, 1997). Banyak individu yang mencari layanan konseling ingin mengintegrasikan pandangan dunia spiritual atau agama mereka ke dalam perawatan kesehatan mental mereka (Aten \& Hernandez, 2004; Worthington \& Sandage, 2001). American Counseling Association (ACA; 2014) menunjukkan dalam kode etiknya bahwa "konselor menghormati keragaman klien" (hal. 5) dan tidak mendiskriminasi klien atas dasar orientasi religius atau spiritual mereka.

Konselor perlu melaksanakan pelatihan dan pengembangan keterampilan yang tepat untuk mengatasi masalah spiritual dan agama klien, sehingga konselor memiliki kompetensi untuk bekerja secara professional mengatasi masalah isu - isu agama dan spiritual dalam konseling (Frame, 2000). Konselor pendidik dan pengawas klinis pada umumnya menganggap diri mereka kurang dalam pelatihan dan latar belakang pengetahuan, yang diperlukan untuk menangani masalah spiritual dan agama secara kompeten dalam konseling atau pengawasan (Aten, Boyd, \& Tucker, 2007; Aten \& Hernandez, 2004; Miller, 2003).

Pengetahuan klinis dan kompetensi berbasis keterampilan untuk konselor telah dikembangkan dan dipromosikan oleh profesi konseling sebagai tanggapan terhadap tuntutan etika dan hukum yang mengatur bidang spiritual dan keagamaan (Kottler \& Shepard, 2011; Remley \& Herlihy, 2001). Kompetensi yang berhubungan dengan konseling ini memberikan standar etika dan pelatihan untuk membimbing perilaku konselor dan pengambilan keputusan dengan tujuan akhir untuk melindungi kesejahteraan klien (Remley \& Herlihy, 2001). Untuk itu, Asosiasi untuk Spiritual, Etika, dan Nilainilai Agama dalam Konseling (ASERVIC) menciptakan 14 kompetensi penting di enam bidang konten untuk melengkapi Kode Etik ACA 


\section{Pengembangan Kompetensi Spiritual Supervisor dalam ...}

(ACA, 2014) dalam memandu terapis/ konselor untuk mengatasi masalah spiritual dan agama dalam konseling dengan lebih baik.

Pengawasan klinis memainkan peran utama dalam menegakkan standar etika dan kompetensi pelaksanaan konseling, terutama melalui evaluasi formal pengetahuan dan keterampilan peserta pelatihan (terapis/ konselor) oleh praktisi yang lebih berpengalaman (Bernard \& Goodyear, 2009). Artikel ini mendeskripsikan alat pengawasan khusus yang dimaksudkan untuk mengembangkan kesadaran etis dan meningkatkan kompetensi klinis secara keseluruhan terkait dengan menangani spiritualitas dalam konseling. Kami telah mengkategorikan masing-masing alat pengawasan dalam kerangka kompetensi spiritual yang didukung ACA (ASERVIC, 2009) untuk membantu supervisor memilih intervensi berdasarkan kebutuhan unik supervisee mereka. Fungsionalitas yang dirasakan dan relevansi alat individu dengan kompetensi spiritual menentukan inklusi mereka dalam artikel ini. Supervisor harus diperingatkan untuk menggunakan alat-alat ini dalam kerangka kode etik yang mengatur profesi konseling dan mungkin ingin merevisi salah satu atau semua alat yang disajikan untuk memenuhi kebutuhan khusus dari pengaturan pengawasan, supervisees, dan klien yang diperlakukan. Selain itu, Supervisor harus memperhitungkan waktu, aksesibilitas, kelembagaan, profesional, dan kendala etika yang mungkin ada dalam kasus khusus mereka karena mereka menilai penerapan masing-masing alat dalam praktik pengawasan mereka sendiri.

Berikut ini dipaparkan 6 konten sebagai landasan empiris bagi kompetensi supervise yang dapat digunakan Supervisor untuk menangani masalah spiritual dan keagamaan dalam konseling (Hull, Suarez dan Hartman, 2015) serta dilengkapi dengan alat pengawasan untuk membimbing supervise dalam meningkatkan kompetensi tersebut.

\section{B. Pembahasan}

\section{Konten Area Komponen I: Budaya dan Pandangan Dunia.}


Pengalaman dengan melibatkan budaya dapat membantu meningkatkan kepekaan terhadap sistem nilai dan kepercayaan baru, terutama ketika hubungan lintas budaya itu ada diantara orangorang yang memiliki pandangan dunia dengan cara yang unik (Sue \& Sue, 2013). Supervisor dapat meningkatkan kepekaan rohani dan agama dalam pengawasan, mendorong supervisee mereka dengan melibatkan kegiatan spiritual baik di dalam maupun di luar hubungan pengawasan. Alat pengawasan berikut ini dimaksudkan untuk menggeser pengetahuan yang beragam, supervisee di luar dari aktivitas spiritual atau praktek keagamaan dan kedalam mempelajari pengalaman tentang dunia realitas kehidupan (Sue \& Sue, 2013).

\section{a. Menghadiri Pertemuan Spiritual}

Pengalaman ini berisi kegiatan belajar yang mempersyaratkan supervisee untuk menghadiri sebuah pertemuan atau perkumpulan spiritual atau keagamaan, yang secara kualitatif berbeda dari sudut pandang dunia pribadi mereka atau mencerminkan system kepercayaan klien dibawah perhatian mereka. Supervisee diminta untuk merefleksikan perasaan, pikiran, dan bias yang mereka rasakan di seluruh pengalaman untuk tujuan memahami nuansa tradisi spiritual / agama yang beragam, mengembangkan kepekaan terhadap pandangan spiritual atau agama klien mereka, dan menunjukkan empati yang lebih kompeten dalam terapi. Supervisor memandu pengalaman ini dengan mendiskusikan atau menyarankan berbagai pilihan pengalaman dengan supervisee sebelum mereka melakukan kunjungan. Supervisor harus menjelaskan kepada supervisee kemungkinankemungkinan yang akan terjadi bila bertemu dengan klien untuk mendiskusikan standar etik yang terkait dengan profesionalisme pada pertemuan spiritual.

Supervisor harus menentukan apakah sepervisee diharuskan untuk melakukan pengalaman ibadah mereka sendiri serta menyampaikan kemungkinan harapan sebelum kegiatan, karena dengan mengikuti pertemuan rohani baru atau berbeda dapat meningkatkan pengalaman afeksi sepervisee. Mengizinkan supervisee untuk menghadiri pertemuan spiritual dengan supervisee lain dapat memberikan tingkat akuntabilitas dan mendorong diskusi tentang pengalaman bersama dari berbagai perspektif, terutama 


\section{Pengembangan Kompetensi Spiritual Supervisor dalam ...}

dalam konteks pengawasan kelompok. Supervisor harus menentukan cara yang paling efektif untuk memproses dan mengevaluasi tingkat pemahaman etika dan spiritual yang dikumpulkan oleh supervisee mereka melalui pengalaman imersi ini. Kami merekomendasikan bahwa Supervisee tidak perlu merefleksikan atau merekam pertemuan spiritual itu, karena mungkin dapat mengganggu atau dianggap tidak peka secara budaya bagi mereka yang hadir. Namun supervisor harus segera memproses pengalaman supervisee ini, untuk merespon kognitif dan afeksi supervisee sebagai hal yang paling penting atau mudah diakses. Supervisor menyarankan agar para supervisee menulis tanggapan reflektif atau merekam catatan harian tentang pengalaman mereka.

\section{b. Pengalaman Multimedia}

Alat-alat audiovisual ini diwajibkan digunakan supervisee untuk menemukan dan meninjau materi spiritual atau keagamaan (misalnya film, documenter, lagu, klip youtube, album ibadah, khotbah atau podcast ceramah). Kami merekomendasikan kepada supervisor untuk mempertimbangkan penggunaan pengalaman multimedia, karena dengan multimedia ini tidak mudah dapat menghadirkan pertemuan spiritual yang dapat ditanggung oleh supervisee mereka. Karena itu mereka memberikan kesempatan kepada supervisor dan supervesee untuk membiasakan diri dengan tradisi spiritual dan budaya yang berbeda dalam konteks pengawasan. Supervisor memandu kegiatan ini dengan memutuskan apakah materi multimedia yang diidentifikasi dapat ditinjau selama atau sebelum sesi pengawasan klinis. Jika materi audiovisual yang dipilih ditinjau selama pengawasan, supervisor harus segera hadir untuk respons kognitif, emosional, spiritual, dan nonverbal supervisee mereka terhadap materi tersebut.

Jika supervisor meminta supervisee mereka untuk berinteraksi dengan materi multimedia sebelum pengawasan, kami menyarankan supervisor untuk menyetujui materi dan memastikan bahwa itu mewakili pandangan dunia spiritual yang sah dan tidak sensitif atau berprasangka. Supervisor juga harus mengklarifikasi untuk supervisee mereka bagaimana cara terbaik untuk mendokumentasikan tanggapan terhadap materi audiovisual di luar pengawasan. Kami merekomendasikan bahwa supervisor mengikuti 
prosedur yang sama untuk refleksi dan mengevaluasi supervisee dari pengalaman sebagaimana diuraikan pada bagian sebelumnya.

Asosiasi Nilai-nilai Spiritual, Etika dan Agama dalam Konseling (ASERVIC) untuk Menangani Masalah Spiritual dan Keagamaan dalam Konseling bisa dilihat pada masing-masing konten. Adapun pada konten pertama bisa dilihat sebagai berikut:

\section{Tabel 1.}

Konten I: Budaya dan Pandangan Dunia sebagai berikut:

Konselor profesional dapat menggambarkan persamaan dan perbedaan antara spiritualitas dan agama, termasuk keyakinan dasar berbagai sistem spiritual, agama-agama besar dunia, agnostisisme, dan ateisme.

Konselor profesional mengakui bahwa kepercayaan klien (atau ketiadaan keyakinan) tentang spiritualitas dan/atau agama adalah pusat dari pandangan dunianya dan dapat mempengaruhi fungsi psikososial.

\section{Konten Area Kompetensi 2: Konseling Kesadaran Diri}

Tugas supervisor yang paling utama adalah memfasilitasi supervisee dalam memahami dan menilai pengaruhnya terhadap klien dan hubungan konseling, khususnya mengenai nilai-nilai, keyakinan, dan ideologi spiritual / keagamaan mereka (Aten \& Hernandez, 2004; Bernard \& Goodyear, 2009; Bishop, Avila-Juarbe, \& Thumme, 2003). Pengawasan melibatkan supervisee yang menantang untuk menjadi introspektif, mengidentifikasi stereotip dan bias, menilai potensi kontratransferensi, dan mengembangkan strategi untuk pengobatan klien etis di berbagai pengaturan. Alat-alat berikut ini dimaksudkan untuk meningkatkan kesadaran sejarah spiritual / religius supervisee 'dan bias potensial sembari mengidentifikasi sumber daya untuk meningkatkan perawatan spiritual / keagamaan etis para klien mereka.

\section{a. Autobiografi Spiritual atau Genogram}

Alat ini mewajibkan supervisee untuk menceritakan sejarah spiritual / keagamaan mereka dalam format tertentu dan menganalisis bagaimana warisan keagamaan / spiritual mereka mempengaruhi pekerjaan mereka dengan klien (Frame, 2000; Peace, 


\section{Pengembangan Kompetensi Spiritual Supervisor dalam ...}

1998; Phifer, 2002; Staude, 2005). Latihan ini juga akan meningkatkan kerja klinis supervisee dan penggunaan alat-alat yang sama ini dengan klien yang dapat mengambil manfaat dari mengeksplorasi bagaimana warisan keagamaan / spiritual mereka memengaruhi fungsi psikososial mereka (Frame, 2000). Supervisor mengarahkan latihan ini dengan menggambarkan ekspektasi format untuk supervisee mereka (yaitu, otobiografi atau genogram) atas dasar berbagai kendala dari hubungan pengawasan. Kami merekomendasikan menggunakan format otobiografi spiritual jika waktu memungkinkan karena variasi alat ini cenderung menghasilkan data spiritual yang lebih rinci dan komprehensif daripada genogram spiritual. Latihan otobiografi spiritual mengharuskan supervisee untuk menuliskan sejarah spiritual mereka dan menyajikannya untuk ditinjau dalam pengawasan. supervisor harus memberikan supervisee mereka dengan tanggal jatuh tempo tertentu, batasan-batasan kata-hitungan, dan garis besar umum untuk membantu supervisee dalam merumuskan otobiografi spiritualnya ke dalam pengaturan yang kohesif.

Genogram spiritual adalah alternatif yang efektif untuk otobiografi spiritual dalam pengaturan pengawasan dalam waktu terbatas karena relatif sederhana dan cepat untuk diproduksi. Mirip dengan genogram keluarga, genogram spiritual mengeksplorasi interaksi, pola, konflik, dan pandangan dunia antargenerasi anggota keluarga sehubungan dengan agama atau spiritualitas melalui peta keluarga (Frame, 2000). Kami merekomendasikan agar genogram spiritual diselesaikan selama pengawasan, dengan supervisor membantu supervisee mereka dalam menciptakan, mendiskusikan, dan mengevaluasi warisan spiritual supervisee.

Penting bagi supervisor untuk memperhatikan kecemasan kinerja supervisesor mereka di seluruh otobiografi spiritual atau kerja genogram. Wajar bagi peserta pelatihan untuk merasa terbuka dan rentan pada tahap awal pengembangan identitas konselor, terutama ketika mereka diminta untuk mengungkapkan informasi pribadi dalam konteks evaluatif (Bernard \& Goodyear, 2009). Supervisor juga harus mengingat bahwa supervisee mungkin merasa lebih nyaman mengekspresikan sejarah spiritual mereka dengan cara yang kreatif, termasuk jurnal tertulis; garis waktu grafis (dengan 
tertinggi dan terendah spiritual); gambar atau kolase foto; buku harian video; atau kreasi seni, musik, atau puisi. Dalam semua kasus,supervisor harus menunjukkan rasa hormat terhadap sejarah spiritual trainee mereka sambil mendedikasikan banyak waktu untuk menganalisis pengaruh latar belakang spiritual / agama peserta pelatihan pada pekerjaan klinisnya.

\section{b. Pembangunan Jaringan Referensi Spiritual}

Alat ini mewajibkan supervisee untuk mengembangkan daftar sumber dari para pemimpin rohani, program, dan layanan yang relevan untuk klien yang membutuhkan perawatan spiritual atau keagamaan khusus (Faiver, Ingersoll, O'Brien, \& McNally, 2001). Tujuan dari alat ini adalah untuk memastikan perawatan yang etis dan kompeten untuk beragam populasi klien dengan menyediakan supervisee dengan peningkatan peluang untuk mengejar konsultasi spiritual, rujukan etis, dan perawatan tambahan yang meningkatkan praktik konseling mereka. Kami menyarankan supervisee mulai membangun hubungan profesional dengan individu atau lembaga dalam jaringan rujukan spiritual mereka untuk meningkatkan kemungkinan kolaborasi, konsultasi, dan rujukan spiritual di masa mendatang. Supervisor mengawasi latihan ini dengan meninjau, memeriksa, dan menyetujui daftar jaringan rujukan spiritual sambil membantu supervisee mereka menentukan praktik terbaik yang terkait dengan rujukan klien.

\section{Tabel 2.}

\section{Konten II: Konseling Kesadaran Diri}

Konselor profesional secara aktif mengeksplorasi sikap, keyakinan, dan nilai-nilai dirinya sendiri tentang spiritualitas dan / atau agama.

Penasihat profesional secara terus-menerus mengevaluasi pengaruh keyakinan dan nilai spiritual dan / atau keagamaannya sendiri pada klien dan proses konseling.

Konselor profesional dapat mengidentifikasi batasan-batasan pemahamannya tentang perspektif spiritual dan / atau keagamaan klien dan berkenalan dengan sumber-sumber spiritual dan spiritual, termasuk para pemimpin, yang dapat menjadi jalan untuk konsultasi dan kepada siapa konselor dapat 
merujuk.

\section{Konten Area Kompetensi 3: Manusiawi dan Pengembangan Spiritual}

Tugas supervisor yang mendasar adalah memantau setiap fungsi dan pengembangan profesional dan etis supervisee baik di ranah teknis maupun pribadi (Bernard \& Goodyear, 2009). Model pengembangan pengawasan sering digunakan untuk membantu supervisor memahami kebutuhan paling penting dari supervisees mereka di berbagai titik sepanjang hubungan pengawasan (Bernard \& Goodyear, 2009; Johnson, 2007). Kami percaya bahwa itu sama bermanfaatnya bagi supervisor untuk membuat konsep keyakinan spiritual atau identitas supervisee mereka melalui lensa perkembangan. Supervisor mungkin merasa terbantu untuk mengkontekstualisasikan diskusi pengawasan tertentu dalam teori atau model spesifik pengembangan keyakinan, terutama ketika isuisu budaya sedang dibahas dalam konseling (Buzzanell, 2009; Parker, 2009). Alat-alat berikut ini dimaksudkan untuk meningkatkan kesadaran supervisee dan penerapan dari teori pengembangan spiritual kepada diri terapis dan masalah atau presentasi klien.

\section{a. Aplikasi Model Pengembangan Iman atau Moral}

Alat ini mewajibkan supervisee untuk mengevaluasi perkembangan sejarah pribadi dan konselor mereka melalui lensa model spiritual, keyakinan, atau pengembangan moral yang dipilih untuk lebih memahami fungsi psikososial mereka. Sangat penting bagi supervisee untuk mengintegrasikan baik perkembangan iman dan teori perkembangan manusia dalam analisis diri mereka. Latihan ini diakhiri dengan supervisee yang mengkonseptualisasikan bagaimana proses perkembangan mereka secara keseluruhan mempengaruhi pekerjaan klinis mereka, terutama dalam kasuskasus di mana tahap perkembangan supervisee saat ini mungkin menyimpang dari klien tertentu di bawah perawatan mereka. Supervisor memandu kegiatan ini dengan memastikan bahwa supervisee mereka akrab dengan keyakinan spesifik atau teori pengembangan moral sebelum menilai sejarah pribadi supervisee. 
Setelah meninjau literatur dengan saksama, supervisee diarahkan untuk terlibat dalam analisis sejarah mereka melalui lensa dari agama yang dipilih atau model pengembangan spiritual dan mempresentasikan temuan mereka dalam pengawasan. Supervisor kemudian harus melibatkan supervisee mereka dalam wacana tentang timbal balik antara iman atau pengembangan moral supervisee dan pengembangan manusia yang berkaitan dengan isuisu diri-terapis di samping bagaimana pengembangan keseluruhan supervisee mungkin terungkap dalam keterampilan klinisnya. Alat ini disimpulkan dengan mendidik supervisee baik pada Model Pengembangan Jangka Panjang (Skovholt \& Ronnestad, 1992) atau Model Pengembangan Terpadu (Stoltenberg, McNeill, \& Delworth, 1998) pengawasan bertujuan untuk supervisees memiliki kontekstualisasi pertumbuhan pribadi mereka dalam mengembangkan kerangka konselor. Supervisor dapat memilih untuk meningkatkan alat ini dengan meminta supervisee mereka melakukan analisis perkembangan pada klien yang saat ini berada di bawah pengawasan supervisee.

\section{b. Mentorship Rohani}

Pembinaan rohani secara tegas berkaitan dengan pengembangan holistik atau spiritual dari seorang profesional baru melalui hubungan dengan pemandu spiritual atau pemimpin (Buzzanell, 2009). Perlu dicatat bahwa supervisor menganggap bimbingan rohani sebagai suplemen, bukan untuk pengganti, pengawasan klinis. Supervisor etis harus menilai kompetensi spiritual mereka sendiri sehubungan dengan kebutuhan spiritual dan profesional supervisee mereka ketika mempertimbangkan untuk menggunakan alat ini. Supervisor mendorong penggunaan mentoring rohani hanya dalam situasi di mana kebutuhan spiritual supervisee mereka yang kompleks melampaui lingkup pengawasan dan ketika kebutuhan spiritual ini memiliki pengaruh langsung pada kompetensi klinis peserta pelatihan.

Sebagai contoh, jika seorang supervisee berada di tengah krisis spiritual eksistensial yang mengakibatkan kontraterferensial klinis, supervisor dapat meminta bantuan seorang mentor spiritual untuk membimbing supervisee melalui ketegangan spiritual sambil memastikan bahwa masalah-masalah klinis yang terkait dengan 


\section{Pengembangan Kompetensi Spiritual Supervisor dalam ...}

kontratransferensi sedang ditangani dalam pengawasan. Supervisor membimbing penggunaan bimbingan rohani dengan mengidentifikasi, memeriksa, dan membangun hubungan rujukan dengan mentor spiritual yang potensial di komunitas mereka. Penting bagi Supervisor untuk menentukan keahlian spiritual dari setiap mentor spiritual potensial dan kesediaan mereka untuk mengambil mentees sebelum membuat rujukan tersebut. Supervisor juga harus menetapkan batas-batas etika dan harapan yang jelas untuk bimbingan rohani, memastikan bahwa baik supervisee dan pembimbing rohani memahami bagaimana pendampingan rohani berbeda dari pengawasan dan konsultasi klinis. Akhirnya, jika supervisor merujuk pembimbing mereka ke mentor spiritual, supervisor harus menjaga komunikasi dengan mentor dan supervisor tentang kualitas dan keefektifan hubungan yang terkait dengan pengembangan profesional keseluruhan pembimbing.

\section{Tabel 3}

\section{Konten III: Pengembangan Manusia dan Spiritual}

Konselor profesional dapat menggambarkan dan menerapkan berbagai model pengembangan spiritual dan / atau agama dan hubungan mereka dengan perkembangan manusia.

\section{Konten Area Kompetensi 4: Komunikasi}

Konseling adalah layanan berorientasi konsumen yang diatur oleh dan didasarkan pada kode etik yang menghormati dan melindungi keragaman dan nilai dari klien / konsumen dan konselor / penyedia (ACA, 2014). Sebagai bagian dari tugas berkelanjutan untuk menghormati keberagaman, para konselor secara etik diberi mandat untuk sepenuhnya sadar akan "nilai, sikap, keyakinan, dan perilaku" mereka sendiri (ACA, 2014, hal. 4) serta dari mereka yang dipegang oleh klien mereka.

Untuk tujuan ini, konselor harus secara efektif mengkomunikasikan batas-batas dan keterbatasan hubungan terapeutik sambil mengungkapkan nilai unik, spesialisasi, dan layanan terapeutik mereka sebagai bagian dari informed consent etis (ACA, 2014). Selain itu, keterampilan komunikasi yang terkait dengan menyelidik, memperjelas, dan memahami pandangan dunia 
klien sangat penting untuk pengembangan profesional konselor, terutama karena berkaitan dengan kompetensi multikultural (Hage, 2006). Demikian pula, supervisor diminta untuk memberitahu supervisee mereka tentang sifat, harapan, dan etika yang mengatur hubungan pengawasan (Bernard \& Goodyear, 2009; Pusat Kredensial dan Pendidikan, 2008) dan untuk melatih supervisee mereka agar kompeten dalam memperlakukan klien dari beragam latar belakang budaya dan agama (Hage, 2006). Tidak mengherankan bahwa supervisee yang secara efektif berkomunikasi tentang isu-isu pengawasan khusus dapat lebih mempersiapkan supervisee mereka untuk menangani masalah-masalah yang sama dalam konseling (Bernard \& Goodyear, 2009; McMahon \& Simons, 2004). Alat-alat berikut ini dimaksudkan untuk meningkatkan komunikasi etis seputar isu-isu spiritual dan keagamaan dalam konseling.

\section{a. Tinjauan Dokumentasi Intake}

Inisiasi etis dari proses konseling selalu mensyaratkan bahwa informed consent dan dokumen asupan dipahami dan diselesaikan secara memadai atau ditandatangani oleh klien (ACA, 2014). Dokumen-dokumen asupan, terutama yang dikembangkan untuk mendapatkan informasi demografis klien, seringkali beragam seperti konteks konseling di mana mereka disediakan. Supervisor bertanggung jawab untuk memiliki pengetahuan tentang dokumen klinis yang digunakan oleh supervisee mereka dan mengawasi pemeliharaan file klinis supervisee mereka. Tanggung jawab ini termasuk pertimbangan cermat kejelasan dan kedalaman yang diberikan informasi spiritual dan agama kepada dan sebaliknya diambil dari klien melalui dokumentasi asupan. Alat ini membutuhkan supervisor untuk meninjau dan menganalisis dokumentasi masukan yang digunakan oleh supervisee mereka untuk konten spiritual. Kami percaya bahwa analisis ini paling baik dilakukan bersama dengan supervisee, memungkinkan kesempatan untuk mendiskusikan seberapa baik dokumen-dokumen asupan menggali data spiritual dan keagamaan. Adalah penting bahwa supervisee mengidentifikasi kekuatan / kelemahan spiritual / agama dan dokumen-dokumen asupan dan mengkritik dokumen-dokumen ini melalui lensa perspektif spiritual atau agama yang beragam. Supervisor dapat lebih meningkatkan analisis ini dengan mendorong 


\section{Pengembangan Kompetensi Spiritual Supervisor dalam ...}

supervisee mereka untuk meminta individu di komunitas lokal mereka untuk memberikan umpan balik tentang relevansi dan akurasi dokumen asupan dari perspektif spiritual dan agama mereka yang unik. Setelah pemeriksaan yang memadai dari dokumentasi intake, para supervisees dapat merevisi atau mengedit dokumendokumen ini (baik secara formal maupun informal) dengan tujuan menciptakan dokumen-dokumen yang lebih sensitif secara budaya atau sensitif secara rohani untuk digunakan dengan beragam klien. Supervisor harus meninjau dokumen yang telah direvisi dengan supervisee mereka dan mendiskusikan potensi bias spiritual yang mungkin tidak dapat dihindari.

\section{b. Pengembangan Pernyataan Pemberitahuan Profesional}

Pernyataan pemberitahuan profesional adalah dokumen tertulis yang mengkomunikasikan informasi terkait tentang parameter dan kondisi hubungan bantuan profesional (Bernard \& Goodyear, 2009). Alat ini mewajibkan supervisee untuk menulis pernyataan pengungkapan yang dipersonalisasi yang menggambarkan keahlian klinis mereka, tingkat pendidikan atau pelatihan, dan pendekatan teoritis terhadap konseling, termasuk bagaimana mereka menangani isu-isu keragaman (misalnya, spiritual, agama) dalam konseling. Kami merekomendasikan bahwa supervisor meninjau ulang pengungkapan yang ada, perjanjian, dan templat kontrak sebagaimana yang digariskan oleh Smith (2011) atau Bernard dan Goodyear (2009) saat membuat pernyataan ini. Supervisor memfasilitasi latihan ini dengan meninjau pernyataan pengungkapan tertulis dari supervisee untuk mengonfirmasi penggunaan bahasa yang etis, akurat, dan peka budaya di seluruh dokumen. Kami merekomendasikan bahwa supervisor juga menjaga terhadap penggunaan jargon spiritual dan religius (misalnya, terlahir kembali, karma, chakra, keesaan, transenden) dalam pernyataanpernyataan ini sebagai cara untuk mengurangi kebingungan pembaca. Supervisor dapat mengadvokasi untuk penggunaan pernyataan pengungkapan yang disetujui dalam konseling sebagai batu loncatan bagi supervisee mereka untuk berbicara dengan klien tentang dimensi etika, spiritual, dan religius konseling sebelum informed consent diperoleh. 
Tabel 4.

Konten IV: Komunikasi

Konselor profesional menanggapi komunikasi klien tentang spiritualitas dan / atau agama dengan penerimaan dan kepekaan.

Konselor profesional menggunakan konsep spiritual dan / atau agama yang konsisten dengan perspektif spiritual dan / atau keagamaan klien dan yang dapat diterima oleh klien.

Konselor profesional dapat mengenali tema-tema spiritual dan / atau religius dalam komunikasi klien dan mampu menangani hal-hal ini dengan klien ketika mereka secara terapeutik relevan.

\section{Konten Area Kompetensi 5: Penilaian}

Penilaian yang sesuai dan sensitif secara budaya diamanatkan oleh Kode Etik ACA (ACA, 2014), khususnya mengenai bagaimana konselor mengumpulkan informasi klien dan menjelaskan penilaian. Banyak lembaga konseling memerlukan penilaian klien yang komprehensif tentang asupan yang mencakup penyelesaian wawancara terstruktur berdasarkan seperangkat standar pertanyaan yang telah ditentukan sebelumnya. Sangat penting bahwa konselor pemula menerima pelatihan yang memadai dalam proses penilaian khusus yang digunakan oleh situs atau lembaga yang mempekerjakan mereka. Supervisor bertanggung jawab untuk memantau kompetensi supervisee mereka dalam penggunaan dan implementasi strategi penilaian sambil menghitung kebutuhan dan perspektif beragam klien (Bernard \& Goodyear, 2009). Alat-alat berikut ini dimaksudkan untuk melihat seberapa banyak masalah spiritual dinilai dalam konseling sambil mempromosikan penggunaan yang kompeten dan pelaksanaan penilaian dan prosedur asupan yang sensitif secara rohani.

\section{a. Review Proses Penilaian}

Alat ini mewajibkan supervisee untuk meninjau dan menganalisis semua penilaian dan protokol wawancara asupan yang digunakan di situs konseling mereka saat ini untuk konten spiritual. 


\section{Pengembangan Kompetensi Spiritual Supervisor dalam ...}

Supervisee akan menyajikan temuan mereka dalam pengawasan dan mendiskusikan seberapa baik proses penilaian dan pengambilan memenuhi kebutuhan spiritual beragam klien. Dalam hal bahwa penilaian dan prosedur asupan dianggap kurang dalam hal mengatasi masalah spiritual dalam konseling, supervisees harus siap untuk menyarankan cara-cara untuk mempertanggungjawabkan dengan lebih baik variabel spiritual dan agama sepanjang proses. Supervisor memandu latihan ini dengan memantau keakuratan evaluasi bawahan mereka tentang penilaian dan prosedur asupan yang digunakan dengan klien mereka. Kami merekomendasikan bahwa supervisor mengamati supervisee mereka (langsung atau direkam) ketika mereka melakukan penilaian klien atau wawancara penerimaan jika dan ketika konteks pengawasan memungkinkan. Pengamatan formal dari penilaian dan proses pengambilan memberikan kesempatan bagi supervisor untuk memberikan umpan balik yang lebih akurat dan kuat kepada supervisee mereka pada kompetensinya dalam melaksanakan wawancara dan penilaian itu sendiri. Selain itu, observasi memungkinkan pengawas untuk merekomendasikan keterampilan khusus untuk supervisee mereka untuk bekerja dalam penilaian masa depan dan wawancara asupan dan untuk menjadwalkan observasi tindak lanjut untuk mengevaluasi pertumbuhan bawahan mereka yang terkait dengan keterampilan ini. Supervisor menyimpulkan latihan ini dengan mengadvokasi revisi terhadap penilaian dan protokol asupan yang ada untuk tujuan meningkatkan pemahaman supervisee tentang perspektif spiritual dan keagamaan unik yang dipegang oleh klien mereka. Pada kesempatan langka bahwa supervisor menganggap proses penilaian dan pengambilan tidak etis atau mengharuskan supervisee untuk menyelesaikan pelatihan tambahan, supervisor harus memastikan bahwa situs, peserta pelatihan, atau keduanya menjadi sesuai dengan standar yang ditetapkan oleh profesi konseling yang terkait dengan klien yang kompeten dan etis penilaian.

\section{b. Skala Pengawasan dalam Masalah Spiritual}

Skala Pengawasan dalam Masalah Spiritual (SISS; Miller, 2003; Miller, Korinek, \& Ivey, 2004) mengeksplorasi frekuensi di mana spiritualitas dibahas di empat faktor: (a) sistem klien, (b) 
sistem pengawasan, (c) ) lensa keragaman, dan (d) lensa makna dan nilai-nilai. Data telah menunjukkan bahwa SISS adalah ukuran yang dapat diandalkan ketika mengumpulkan persepsi supervisee komunikasi spiritual dalam pengawasan (Miller et al., 2004) serta ketika membandingkan persepsi supervisor dan supervisee dari dialog yang diinfuskan secara spiritual dalam pengawasan diad (Hull, Suarez, Sells, \& Miller, 2013). Alat ini membantu supervisor dalam menilai di mana dan berapa banyak (atau seberapa kecil) spiritualitas sedang dibahas di domain pengawasan dan konseling yang spesifik, termasuk proses penilaian konseling (Miller, 2003). Supervisor mengarahkan penggunaan SISS dengan memperkenalkan alat ini lebih awal dalam hubungan pengawasan untuk tujuan mengembangkan pemahaman mendasar tentang pengalaman dialog spiritual supervisee mereka dalam pengawasan.

Pemahaman supervisor tentang variabel kompleks yang mempengaruhi persepsi awal supervisee dari wacana spiritual dalam pengawasan dapat ditingkatkan dengan menggunakan SISS bersama dengan penilaian berbasis kompetensi lainnya, seperti Skala Kompetensi Spiritual (Dailey, Robertson, \& Gill, 2015). Supervisor harus terus menggunakan SISS di seluruh pengawasan untuk memantau dan menyesuaikan frekuensi dialog spiritual dengan supervisee mereka dan di mana itu terjadi. Supervisor harus memberi perhatian khusus apakah supervisee mereka menganggap diskusi spiritual terjadi ketika masalah penilaian ditangani dalam pengawasan. Kami merekomendasikan bahwa baik supervisor dan supervisee menyelesaikan SISS dan membandingkan skor sebagai jalan potensial untuk menginformasikan keakuratan persepsi mereka mengenai komunikasi spiritual yang terjadi dalam hubungan pengawasan mereka. Ketika skor mereka di SISS berbeda, supervisor harus memfasilitasi wacana pengawasan dengan supervisee mereka mengenai alasan potensial untuk perspektif yang berbeda ini. Seperti halnya alat penilaian, supervisor harus mengikuti prosedur standar yang terkait dengan informed consent dan kerahasiaan ketika menggunakan SISS dalam pengawasan.

\section{Tabel 5.}

Konten V: Penilaian 
Selama proses pengambilan dan penilaian, konselor profesional berusaha memahami perspektif spiritual dan / atau keagamaan klien dengan mengumpulkan informasi dari klien dan / atau sumber lain.

\section{Konten Area Kompetensi 6: Diagnosa dan Perawatan}

Klien yang mencari layanan konseling sering ingin mengintegrasikan pandangan dunia spiritual atau agama mereka ke dalam pengobatan (Aten \& Hernandez, 2004; Worthington \& Sandage, 2001). Konselor yang berlangganan pandangan dunia spiritual atau religius cenderung lebih terbuka untuk menerapkan intervensi spiritual atau agama dalam konseling (Walker, Gorsuch, \& Tan, 2005). Namun, terapis yang sama ini sering menghindari penerapan intervensi spiritual atau perawatan dalam konseling karena kurangnya bukti memvalidasi modalitas tersebut dalam pengaturan klinis (Walker et al., 2005). Selain itu, penyalahgunaan modalitas spiritual / agama tertentu oleh beberapa orang telah diterjemahkan ke dalam banyak yang waspada terhadap penggunaan mereka sama sekali. Kurangnya pertimbangan yang diberikan untuk efek variabel budaya pada fungsi manusia dan kriteria diagnostik berkaitan dalam profesi di mana diagnosis klinis sering menentukan akses dan durasi pengobatan konseling (Dailey, Gill, Karl, \& BarrioMinton, 2014). Alat-alat berikut akan membantu konselor-dalampelatihan dalam menentukan bantalan bahwa variabel budaya seperti spiritualitas dan religiusitas memiliki baik pada diagnosis kesehatan mental dan kemungkinan pengobatan.

\section{a. Studi Kasus Spiritual / Keagamaan}

Alat ini mewajibkan supervisee untuk memilih klien tentang beban kasus mereka saat ini yang spiritualitas atau religiositasnya berpengaruh pada presentasi psikososialnya. Dalam hal supervisee tidak memiliki klien spiritual atau religius dalam beban kasus mereka, alat ini dapat direvisi dengan menyediakan para supervisee dengan klien fiktif yang menyajikan masalah spiritual / agama. Supervisee membuat laporan spiritual-biopsikososial berdasarkan data psikososial yang dikumpulkan selama pengobatan. Lembaga kesehatan mental masyarakat dan praktikum atau buku teks magang sering memiliki templat untuk mengumpulkan riwayat psikososial 
dan membuat laporan kasus semacam ini (Scott, Boylan, \& Jungers, 2014).

Supervisees juga mengembangkan rencana perawatan klinis untuk klien yang dipilih untuk hadir untuk ditinjau dalam pengawasan. Rencana perawatan harus mencakup diagnosis sementara untuk klien dan tujuan pengobatan potensial berdasarkan diagnosis yang diberikan yang memperhitungkan kekuatan / defisit spiritual / agama klien. Kami merekomendasikan bahwa, jika mungkin, supervisee juga menyerahkan rekaman klien terpilih yang mendiskusikan fungsi spiritual / keagamaannya dalam konseling untuk melengkapi studi kasus tertulis dan laporan rencana perawatan. Supervisor mengarahkan kegiatan ini dengan menyediakan supervisee mereka dengan template atau harapan untuk laporan spiritual-biopsikososial dan rencana perawatan untuk membantu peserta pelatihan mereka dalam memproduksi dokumendokumen ini. Supervisor akan meninjau laporan dan rekaman yang sudah dipersiapkan supervisee (jika tersedia) untuk mengonfirmasi diagnosis sementara supervisee untuk klien yang teridentifikasi. Setelah diagnosis yang akurat ditegaskan, supervisor dapat mendiskusikan tujuan pengobatan yang dipilih untuk klien ini dengan supervisee mereka. Supervisor menyimpulkan latihan ini dengan mendukung validitas dari tujuan perawatan yang dipilih supervisee mereka atau meminta bahwa pembimbing mereka merevisi tujuan perawatan untuk lebih bertanggung jawab terhadap fungsi spiritual dan keagamaan klien dan simtomatologi.

\section{b. Mengembangkan Kotak Alat Intervensi Spiritual}

Alat ini mewajibkan supervisee untuk meneliti dan mengidentifikasi intervensi spiritual atau keagamaan tertentu yang tersedia untuk digunakan dalam konseling, termasuk tetapi tidak terbatas pada perhatian, pencatatan spiritual, dan meditasi. Kami merekomendasikan merujuk supervisee ke sumber daya atau buku teks - seperti karya Aten, McMinn, dan Worthington (2011) - yang memperkenalkan dan menjelaskan penggunaan etis dari intervensi spiritual dalam konseling. Supervisee membuat kotak alat intervensi spiritual di mana setiap intervensi spiritual yang diidentifikasi atau dipilih dijelaskan, masalah etika digambarkan, protokol pengobatan dibatasi, dan tingkat pelatihan atau pengalaman yang diperlukan 


\section{Pengembangan Kompetensi Spiritual Supervisor dalam ...}

untuk menerapkan masing-masing modalitas ditentukan. Supervisee kemudian menyajikan kotak peralatan yang sudah selesai dalam pengawasan untuk ditinjau dan disetujui. Supervisor memfasilitasi latihan ini dengan meninjau intervensi spiritual yang dipilih dengan supervisor mereka dan secara kolaboratif menentukan populasi klien tertentu yang dapat mengambil manfaat dari setiap modalitas. Akhirnya, supervisor menyediakan pengawasan berkelanjutan atas inisiatif kompeten dan etis kompeten dari intervensi spiritual yang dipilih dalam konseling.

\section{Tabel 6.}

\section{Konten VI: Diagnosa dan Pengobatan}

Ketika membuat diagnosis, konselor profesional mengakui bahwa perspektif spiritual dan / atau keagamaan klien dapat a) meningkatkan kesejahteraan; b) berkontribusi terhadap masalah klien; dan / atau c) memperburuk gejala.

Konselor profesional menetapkan tujuan dengan klien yang konsisten dengan perspektif spiritual dan / atau agama klien.

Konselor profesional mampu a) memodifikasi teknik terapeutik untuk memasukkan perspektif spiritual dan / atau religius klien, dan b) menggunakan praktik spiritual dan / atau keagamaan sebagai teknik bila sesuai dan dapat diterima oleh sudut pandang klien.

Konselor profesional dapat secara terapeutik menerapkan teori dan penelitian saat ini mendukung dimasukkannya perspektif dan praktik spiritual dan / atau keagamaan klien.

\section{Simpulan}

Tujuan utama dari artikel ini adalah untuk memandu supervisor klinis dalam mengidentifikasi, memilih, dan mengimplementasikan perangkat pengawasan yang mempromosikan pengembangan supervisee kompetensi spiritual yang digariskan oleh ASERVIC (2009). Kami berasumsi bahwa alatalat yang diuraikan dalam artikel ini hanya diterapkan dalam batasan etis yang ditetapkan oleh profesi konseling dan sesuai dengan batasan profesional dari masing-masing supervisor dan supervisee. Untuk tujuan ini, kami menyarankan bahwa supervisor 


\section{Diana Dewi Wahyuningsih}

mengkonseptualisasikan alat yang dijelaskan dalam artikel ini dalam orientasi supervisee khusus atau model yang ada supervisee (Bernard \& Goodyear, 2009) sementara mengikuti pedoman berorientasi spiritual untuk supervisee (Aten \& Hernandez, 2004; Parker, 2009; Polanski, 2003; Ripley, Jackson, Tatum, \& Davis, 2007; Weiss Ogden \& Sias, 2010 ). Tujuan kedua dari artikel ini adalah untuk meningkatkan fokus dan diskusi spiritualitas dalam pengawasan dan konseling. Ketika masalah spiritual semakin diperhatikan, kami percaya bahwa akan ada peningkatan bersamaan dalam wacana spiritual dan penekanan pada masalah spiritual / keagamaan dalam konseling. Penelitian masa depan dapat mengukur seberapa baik dan sejauh mana perhatian spiritual dalam pengawasan berkorelasi dengan pengembangan kompetensi spiritual dalam konseling untuk tujuan membangun praktik terbaik untuk mengatasi masalah spiritual dan agama baik dalam konseling dan pengawasan. 


\section{Pengembangan Kompetensi Spiritual Supervisor dalam ...}

\section{DAFTAR PUSTAKA}

American Counseling Association. (2014). ACA code of ethics. Alexandria, VA: Author.

Association for Spiritual, Ethical, and Religious Values in Counseling. (2009). Competencies for Addressing Spiritual and Religious Issues in Counseling. Retrieved from

Aten, J. D., \& Hernandez, B. C. (2004). Addressing religion in clinical supervision: A model. Psychotherapy: Theory, Research, Practice, Training, 41, 152-160.

Bernard, J. M., \& Goodyear, R. K. (2009). Fundamentals of clinical supervision (4th ed.). Needham Heights, MA: Allyn \& Bacon.

Frame. W. Marsha. (2000). Spiritual and Religious Issues in Counseling: Ethical Considerations. THE FAMILY JOURNAL: COUNSELING AND THERAPY FOR COUPLES AND FAMILIES, Vol. 8 No. 1, January 2000 72-74 (C) 2000 Sage Publications, Inc.

Fukuyama. A. Mary \& Sevig. D. Todd (1997). Spiritual Issues in Counselling: A New Course. JOURNAL COUNSELOR EDUCATION AND SUPERVISION / MARCH 1997 / VOL. 36

http://www.aservic. org/resources/spiritual-competencies/

Hull. E. C; Suarez. C. E \& Hartman. D. (2015). Developing Spiritual Competencies in Counseling: A Guide for Supervisors. the American Counseling Association. All rights reserved. Counseling and Values, April 2016, Volume 61

Kottler, J. A., \& Shepard, D. S. (2011). Introduction to counseling: Voices from the field (7th ed.). Belmont, CA: Brooks/Cole.

Parker, S. (2009). Faith development theory as a context for supervision of spiritual and religious issues. Counselor Education and Supervision, 49, 39-53.

Remley, T. P., \& Herlihy, B. (2001). Ethical, legal, and professional issues in counseling. Upper Saddle River, NJ: Prentice Hall.

Scott, J., Boylan, J. C., \& Jungers, C. M. (2014). Practicum and internship: Textbook and resource guide for counseling and psychotherapy. New York, NY: Routledge.

Sue, D. W., \& Sue, D. (2013). Counseling the culturally diverse: Theory and practice (6th ed.). Hoboken, NJ: Wiley. 
Diana Dewi Wahyuningsih

Walker, D. F., Gorsuch, R. L., \& Tan, S. Y. (2005). Therapists' use of religious and spiritual interventions in Christian counseling: $A$ preliminary report. Counseling and Values, 49, 107-119. 